This document is the accepted manuscript version of the following article: Jassey, V. E. J., Chiapusio, G., Binet, P., Buttler, A., Laggoun-Défarge, F., Delarue, F., ... Gilbert, D. (2013). Above- and belowground 1inkages in Sphagnum peatland: climate warming affects plant-microbial interactions. Global Change Biology, 19(3), 811-823. https://doi.org/10.1111/gcb.12075

\title{
Above- and belowground linkages in Sphagnum-peatland: climate warming affects plant-microbial interactions
}

Vincent EJ Jassey ${ }^{1,2,3}$ *, Geneviève Chiapusio ${ }^{1}$, Philippe Binet ${ }^{1}$, Alexandre Buttler ${ }^{1,2,3}$, Fatima Laggoun-Défarge ${ }^{4,5,6}$, Frédéric Delarue ${ }^{4,5,6}$, Nadine Bernard ${ }^{1}$, Edward AD Mitchell ${ }^{5}$, MarieLaure Toussaint $^{1}$, André-Jean Francez ${ }^{6}$, Daniel Gilbert ${ }^{1}$

${ }^{1}$ Université de Franche-Comté - Laboratoire Chrono-Environnement, UMR CNRS/UFC 6249, F25211 Montbéliard cedex, France.

${ }^{2}$ Ecole Polytechnique Fédérale de Lausanne EPFL, Ecological Systems Laboratory ECOS, Station 2, 1015 Lausanne, Switzerland

${ }^{3}$ Swiss Federal Research Institute WSL, Site Lausanne, Station 2, 1015 Lausanne, Switzerland

${ }^{4}$ Université d'Orléans, ISTO, UMR 7327, 45071 Orléans, France

${ }^{5}$ CNRS/INSU, ISTO, UMR 7327, 45071 Orléans

${ }^{6}$ BRGM, ISTO, UMR 7327, BP 36009, 45060 Orléans, France ${ }^{7}$ University of Neuchâtel, Laboratory of Soil Biology, Rue Emile-Argand 11, CH-2000 Neuchâtel, Switzerland

${ }^{8}$ Université de Rennes 1, CNRS UMR 6553 ECOBIO 'Ecosystèmes, Biodiversité, Evolution' \& FR 90 CAREN, Campus de Beaulieu, F-35042 Rennes cedex, France

* Corresponding author; phone: +41 (0) 2169339 06; fax: +41 (0) 216933913

E-mail address: vincent.jassey@epfl.ch (V.E.J. Jassey)

Running title: Warming affects plant-microbial interactions

Keywords: aboveground, belowground, climate warming, microbial communities, peatlands, polyphenols, testate amoebae, plant-soil-microorganism interactions, SEM 


\begin{abstract}
Peatlands contain approximately one-third of all soil organic carbon (SOC). Warming can alter above- and belowground linkages that regulate soil organic carbon dynamics and Cbalance in peatlands. Here we examine the multi-year impact of in-situ experimental warming on the microbial food web, vegetation, and their feedbacks with soil chemistry. We provide evidence of both positive and negative impacts of warming on specific microbial functional groups, leading to destabilisation of the microbial food web. We found that warming involved a strong reduction $(70 \%)$ of the biomass of top-predators (testate amoebae). Such a loss caused a shortening of microbial food chains, which in turn stimulated microbial activity, leading to slight increases in levels of nutrients and labile $\mathrm{C}$ in water. We further show that warming altered the regulatory role of Sphagnum-polyphenols on microbial community structure with a potential inhibition of top-predators. In addition, we found that abundance of Sphagnum decreased, whereas that of vascular plant increased with warming. Using structural equation modelling, we show that changes in the microbial food-web affected the relationships between plants, soil water chemistry and microbial communities. These results suggest that warming will destabilize $\mathrm{C}$ and nutrient recycling of peatlands via changes in above- and belowground linkages, and therefore, the microbial food web associated with mosses will feedback positively to global warming by destabilizing the carbon cycle. In addition, our findings add another crucial new contributor to the list of mechanisms by which mosses, as ecosystem engineers, tightly regulate peatland functioning.
\end{abstract}




\section{Introduction}

Ongoing global warming is causing ecological communities to rapidly change, resulting in modifications to their interactions, and to ecosystem functioning and services. Climate warming phenomena can directly affect aboveground communities, by changing plant community composition, carbon allocation patterns, or the quality of plant-derived organic matter, which indirectly affect soil biota (Wardle et al., 2004; Veteli et al., 2007; De Dyn et al., 2008; Wardle et al., 2012). The microbial subsystem in turn supports a wide range of key ecosystem processes by breaking down plant material, and therefore determines the nature and the extent of plant community and functioning (Wardle et al., 2004; Bardgett et al., 2008; Singh et al., 2010). Aboveground-belowground linkages and feedbacks may respond strongly to climate change yet such integrated effects remain poorly quantified (Singh et al., 2010; Eiseinhauer et al., 2012). Understanding warming-induced changes on plants and soil organisms is highly relevant to the growing interest that these components have in driving terrestrial ecosystem processes, both above- and belowground (Wardle \& Bardgett, 2002; Bardgett \& Wardle, 2010).

Peatlands dominated by Sphagnum mosses store more C than any other terrestrial ecosystem owing to imbalance between litter inputs and $\mathrm{C}$ outputs from soil respiration (Davidson \& Janssens 2006; Dise 2009). Complex linkages between above- and belowground communities regulate this C-sequestration, which may decrease or even reverse in response to warming, leading to a positive feedback to global warming (Bardgett et al., 2008; Dorrepaal et al., 2009; Fenner \& Freeman 2011). However, despite recent interest in linkages between above- and belowground communities as powerful mutual drivers of ecosystem processes (Wardle, 2006; Ward et al., 2007; Kardol \& Wardle, 2010; Wardle et al., 2012), only a limited number of field experiments considering response to ecosystem change have been conducted in peatlands (Fenner et al., 2007; Kim et al., 2012; Weddon et al., 2012). 
Knowledge of how climate warming impacts on the mechanisms behind above- and belowground linkages in peatlands is currently insufficient. Indeed, changes in linkages at one level of organization (e.g. species characteristics and interactions, community composition or carbon storage) can affect above- and belowground biota, and their linkages, at other levels of organization, thus destabilizing peatland functioning.

Monitoring study had shown how peat mosses (Sphagnum fuscum) stabilised vegetation composition in response to climate warming by encroaching on vascular plant space (Keuper et al. 2011), underlying the key role of Sphagnum in peatlands. By efficiently accumulating nutrients, Sphagnum mosses act as ecosystem engineers, creating unfavourable conditions to vascular plant life (van Breemen, 1995; Turetsky, 2003; Gunnarsson, 2005). These mosses are also tightly linked to microbial communities through a variety of both direct and indirect mechanisms that ultimately exert control on peatland ecosystem $\mathrm{C}$ dynamics (Lindo \& Gonzalez, 2010). Microbial communities living in Sphagnum mosses constitute a crucial detrital network for nutrient and $\mathrm{C}$ cycling, where protozoans (and especially testate amoebae) play a central role (Gilbert et al., 1998; Mitchell et al., 2003; Lindo \& Gonzalez, 2010). Sphagnum also produces organochemical compounds such as polyphenols, which are known to have a strong inhibitory effect on microbial breakdown of organic matter, therefore favouring peat accumulation (Verhoeven \& Toth, 1995). For instance, a reduction in polyphenol content may stimulate bacterial and microbial enzymatic activity (Fenner \& Freeman, 2011; Jassey et al., 2011a). However, despite the global significance of microbial communities in SOC dynamics of peatlands, their sensitivity to climate change has so far received little attention (Jassey et al., 2011b; Kim et al., 2012; Tsyganov et al., 2012; Weddon et al., 2012) and considerable gaps remain in our understanding of the impacts of warming on aboveground-belowground relationships in peatlands following changes in microbial components. Long-term global warming is expected to considerably alter peat- 
forming areas, potentially involving substantial $\mathrm{C}$ loss due to modifications in microbial processes linked to Sphagnum mosses (Dorrepaal et al., 2009; Delarue et al., 2011; Fenner \& Freeman, 2011; Jassey et al., 2011a,b). Understanding key mechanisms behind the changing Sphagnum - microbial - vascular plant interactions in responses to climate change, is obviously needed to better understand ongoing processes and to predict more accurately future changes in the functioning of peatlands.

In this paper, we focus on the ways in which warming affects above- and belowground subsystems as key components of C fluxes in Sphagnum-peatlands. Specifically, we analyse the effect of climate warming on key above- and belowground components in a Sphagnum peatland in the Jura Mountains (France) to explore whether changes in peatland properties will be brought by plant communities, microbial communities, or by interactions between the two. Our aims were to (1) quantify over the course of two years how the soil microbial food web (biomass of bacteria, fungi, protozoans, and metazoans), plants communities (species composition and diversity), Sphagnum-polyphenols and soil water chemistry composition changed in response to warming, and (2) to clarify whether climate warming destabilized peatland functioning by changing plant-soil-microbial interactions, including polyphenol phytochemical interactions. Linkages amongst these variables were investigated using a pathrelation network and structural equation models (SEM) to gain a mechanistic understanding of how warming effects materialized on above- and belowground linkages. 


\section{Materials and methods}

\section{Field site and experimental design}

The experimental site is an undisturbed Sphagnum-dominated peatland situated in the Jura Mountains (The Forbonnet peatland, north-eastern France, 46 49'35'’ N, 6¹0'20' 'E). Above(mosses, vascular plants, polyphenols produced by Sphagnum) and belowground (soil water chemistry, microbial communities living in Sphagnum carpet) components were measured across a transitional fen-bog area in June 2008, 2009 and 2010 (begin of the warming experiment April 2008). The experimental site has an area of $30 \mathrm{~m} \times 30 \mathrm{~m}$ and the vegetation consists of a mosaic of hummocks and lawns (Jassey et al. 2011a). The moss layer is dominated by $S$. fallax in lawns and by a mixture of Sphagnum fallax, S. magellanicum and $S$. palustris in hummocks whereas the evergreen dwarf shrubs Eriophorum vaginatum and Andromeda polifolia, the deciduous dwarf shrubs Vaccinum oxycoccus and the graminoids Calluna vulgaris and Carex rostrata characterize the field layer. We chose 12 sampling plots (six ambient and six warmed plots) across the area placed so as to cover all the possible microforms along the gradient. Six plots were placed in lawns and six plots in hummocks, and in each area three plots were assigned as ambient conditions and three as warmed conditions. We used open-top chambers (OTC) to simulate the regional climate expected for the coming decades (IPCC, 2007; Jassey et al., 2011a). The OTCs significantly increased mean air temperature in spring and summer by up to about $1.3^{\circ} \mathrm{C}$, and decreased the water content of Sphagnum in summer by up to about 30\% (Delarue et al., 2011, Jassey et al., 2011a). The water table depth did not change with warming and was ranged from $13.4 \mathrm{~cm}$ to $20.8 \mathrm{~cm}$ between 2008 and 2010. 


\section{Belowground measurements}

We analyzed the entire microbial community using a morpho-type functional group approach rather than focusing on a given group, such as bacteria or fungi. Samples of S. fallax were collected for the study of microbial communities from ten permanent markers in each plot and the average altitude (microtopography) was measured. This sampling design allowed for multiple sampling over time and collection of a composite sample from each plot, avoiding any bias due to spatial heterogeneity (Mitchell et al., 2000a). Microbial communities were analysed from surface $(0-3 \mathrm{~cm})$ and litter $(3-6 \mathrm{~cm})$ layers of Sphagnum shoots. Microbial samples were fixed in glutaraldehyde $(2 \%)$ and extracted following the standard method described in Jassey et al. (2011b). We used direct observation by inverted microscopy (x200 and x400 magnification) to determine precisely the abundance and biomass of individual microbial functional groups (fungi, microalgae, ciliates, testate amoebae, rotifers and nematodes). Flow cytometry (FAC-SCalibur flow cytometer, Becton Dickinson) was used for bacterial counts. Fluorescent microbeads (Molecular probes) of diameter $1 \mu \mathrm{m}$ were added to each sample as an internal standard. Bacterial samples were stained with SYBR Green I (1/10,000 final conc.) for $15 \mathrm{~min}$ in the dark and run at medium speed (ca $40 \mu \mathrm{L} \mathrm{min}{ }^{-1}$ ). For each specimen, the average biovolume $\left(\mu \mathrm{m}^{3}\right)$ was estimated by assuming geometrical shapes using image analysis and converted to biomass using conversion factors (Gilbert et al., 1998). Data were expressed as micrograms of carbon per gram of Sphagnum dry mass ( $\left.\mu \mathrm{gC} \cdot \mathrm{g}^{-1} \mathrm{DM}\right)$.

The trophic position of testate amoebae was also estimated by measuring their body size and their shell-aperture size using image analysis. We chose these two specific morphological traits because they are linked to their feeding habit. The species with a low ratio shell aperture size over body size $(0<$ shell-aperture size/body size $<0.18)$ were considered as having a low trophic position (i.e. primarily bacterivors and algivors), and species with a high one $(0.20<$ shell-aperture size/body size $)$ as having a high trophic 
position (i.e. primarily predators of other protists and micro-metazoan) in the microbial food web (Yeates \& Foissner, 1995; Mitchell et al., 2003; Jassey et al., 2012).

Water chemistry $(20 \mathrm{~mL})$ was analysed in each sampling plot at $10 \mathrm{~cm}$ depth from piezometers during each sampling campaign. Total dissolved nitrogen (DN) and dissolved organic carbon (DOC) of peatland water were determined with a SHIMADZU SSM-5000A total $\mathrm{C}$ and $\mathrm{N}$ analyser. Ammonium $\left(\mathrm{NH}_{4}{ }^{+}\right)$, nitrates $\left(\mathrm{NO}_{3}{ }^{-}\right)$and phosphates $\left(\mathrm{PO}_{4}{ }^{3-}\right.$ and total phosphorus) were analysed colorimetrically using a continuous flow analyser (FLOWSYS, Systea, Roma) after filtering the bog water at $0.45 \mu \mathrm{m}$.

\section{Aboveground measurements}

We performed vegetation surveys by the point-intercept method (Buttler, 1992; Keuper et al., 2011). We used a 50x50 cm Plexiglas frame placed above a permanently marked quadrat by means of 4 adjustable poles. A ruler with 20 holes was moved along 20 different positions to obtain 400 measuring points. A metal pin with a $1 \mathrm{~mm}$ diameter tip was lowered through each hole in the ruler and each contact of the pin with green living vegetation was recorded by species until the pin reached the moss substrate. Moss and vascular plant abundances were expressed as percentage of mean number of hits $(\%)$. Moreover, we measured the average microtropography of the marked vegetation quadrat.

Total water-soluble Sphagnum-polyphenols were quantified in living segments of Sphagnum shoots $(0-6 \mathrm{~cm})$ during each sampling campaign using Folin methods and gallic acid as standard (see Jassey et al., 2011b for details). These samples were collected around the same ten permanent markers used for microbial communities for each plot.

\section{Numerical analyses}


We carried out linear mixed effects models and ANOVAs to test for differences between treatments and years in the following variables: (i) biomass of individual microbial groups; (ii) abundance of individual testate amoeba species; (iii) individual water chemical components; (iv) total abundance of plants (mosses and vascular plants) and abundance of individual moss and vascular plant; and (v) polyphenol content in Sphagnum. Linear mixed effects were used to assess the effects of warming (difference of temperature between ambient and warmed plots, delta TC), time and microtopography (fixed effects) on measured of biotic and abiotic variables while accounting for the temporal repeated measurements in each plot on three dates. We fitted all models including plot as a random effect on the intercept, i.e. we corrected for the inflation of the residual degrees of freedom that would occur if we were using repeated measurements as true replicates (Pinheiro and Bates, 2000). Then ANOVAs were applied on the different models to test the fixed effects, and differences among the levels of the fixed effects in the final model were determined using multiple comparison post-hoc analyses (general linear hypothesis test). Finally, we used the $F$-values from the ANOVAs to quantify the impact of warming on the abundance of individual testate amoeba species. Higher $F$-values indicated stronger warming effect on the individual testate amoeba species.

We evaluated the warming effect on vegetation and microbial community structure, and water chemistry composition using the principal response curve (PRC) method. PRC was used to focus on the time-dependent treatment effect and applied on the Hellingertransformed vegetation and microbial assemblages and the standardized water chemistry matrix, including the response of individual plant species, microbial groups or chemical components. PRC analysis is a special case of partial RDA (pRDA) for multivariate responses in repeated observation design. It is based on a pRDA adjusted for overall changes in community structure response over time, as compared to control plots (van den Brink and ter Braak, 1999). In diagrams, the curves represent the time trajectory for the controls as a 
horizontal line maintained to 0 (dashed line) and deviation of community structure in warmed plots in course of two years (solid line). This is achieved by taking the control treatment as the reference against which the other treatments are contrasted and by defining "time" as the horizontal axis of the diagram (van den Brink and ter Braak, 1999). With the help of the species weights on the right $\mathrm{Y}$-axis, the PRC can be used to infer about the response of individual species to warming. The species scores on the right $\mathrm{Y}$-axis allow an interpretation at the species level, i.e. values indicate the contribution of individual species/group/component to the deviation of the community structure observed in warmed plots. Individual group with positive scores on right $\mathrm{Y}$-axis are inferred to show a negative effect of warming, whereas groups with negative scores show a positive response to warming. A group near zero scores either show no response or a response unrelated to the pattern shown in PRC. Higher values (positive or negative) on the right $\mathrm{Y}$-axis indicate stronger warming effect on the individual species/group. Permutation tests with 1,000 permutations, stratified by year, were performed for every canonical axis. Additionally, variance partitioning using redundancy analyses (RDA) and adjusted $R^{2}$ were applied to compare the respective effect of microtopography, time and warming on each biotic and abiotic matrices. The significance of the each explanatory variables included in RDA were tested using 1,000 permutations.

Above- and belowground data was organized into a path-relation network and subjected to structural equation modelling (SEM) (Grace \& Keeley, 2006; Grace et al., 2007, 2010). This enabled us to explore simultaneous influences of several potentially important drivers of peatland functioning that may be affected by warming, and thereby identify their relative importance to obtain a better understanding of peatland response to warming. SEM was based on the overall dataset and predicted causal relationships between variables were based upon prior knowledge, theory and past experience on the role of above- and belowground factors in peatland functioning. The adequacy of the model was determined via 
several tests, i.e. $\chi^{2}$ tests, goodness fit index (GFI), Akaike value (AIC), root square mean error of approximation (RMSEA) and root mean square residual (RMR) (Grace \& Keeley, 2006; Jonsson \& Wardle, 2010; Eisenhauer et al., 2012). Adequate model fits are indicated by nonsignificant $\chi^{2}$ tests $(P>0.05)$, high GFI $(0.8<$ GFI $<1)$, low AIC, low RMSEA $(<0.05)$ and low RMR (RMR < 0.05) (Grace et al., 2010). Models were built and separately tested for ambient and warmed plots based on the biomass of individual microbial groups in surface and litter, abundances of mosses and vascular plants, polyphenol content and a subset of four variables (DOC, $\mathrm{NH}_{4}{ }^{+}, \mathrm{NO}_{3}^{-}$and $\mathrm{PO}_{4}{ }^{3-}$ ) retained by stepwise selection from the water chemistry matrix. We used RV-coefficients from multiple factor analysis (MFA) to construct our correlation matrices used in SEM (Legendre \& Legendre, 1998; Grace et al., 2010). MFA symmetrically linked the six groups of descriptors described above. MFA was selected because it allowed the simultaneous coupling of several groups or subsets of variables defined on the same objects and assess the general structure of the data (Escofier \& Pagès, 1994). RVcoefficients (Pearson correlation coefficient) were used to measure the similarities between two data matrices (Robert \& Escoufier, 1976; Josse et al., 2008). SEM was performed using Amos 5 (Amos Development Corporation, Crawfordville, FL, USA). For each analysis, $R^{2}$ values were obtained for each dependent matrix, showing the amount of the variance explained by the model (Grace \& Keely, 2006; Grace et al., 2010; Jonsson \& Wardle, 2010).

All statistical analyses were performed with $\mathrm{R} 2.10 .1$ using the lme, vegan and FactoMineR packages (Husson et al., 2009; Oksanen et al., 2010; R Development Core Team, 2010).

\section{Results}


Belowground subsystem

\section{Microbial network structure}

The structure of microbial communities clearly responded to warming as showed by PRCs

(Fig. 1a, b). Microbial community structure in warmed plots significantly deviated from ambient plots at the surface layers $(F=4.6, P=0.02)$ whereas the same but weaker warming effect was recorded at the litter layers $(F=3.1, P=0.05)$. The response of warmed plots clearly appeared in 2009 in both sampling depth, one year after the beginning of the warming experiment (Fig.1a, b). The respective effects of microtopography, time and temperature increase on the variation of microbial communities living at the surface layers were of $13.7 \%$, $6.6 \%$ and $10.5 \%$, respectively (Table 1 ), while their respective effects at the litter layers were of $0.6 \%, 24.7 \%$ and $14.3 \%$, respectively. Only some microbial groups were affected by microtopography variations (e.g. microalgae and testate amoebae) along Sphagnum shoots (Table S1). Furthermore, RDA and variance partitioning revealed that the interaction between microtopography and warming were not significant along Sphagnum shoots (Table 1), highlighting a similar warming effect amongst lawns and hummocks.

The detailed examination of the time-dependent warming effect on individual microbial groups revealed a strong negative effect on testate amoebae, especially at the surface layers (Fig. 1a; Table S1). This effect was largely due to a decline of the biomass of the testate amoebae with high trophic level $(F=5.6, P=0.002)$ of $40 \%$ and $75 \%$, after one and two warming years respectively. The total biomass of this category of species decreased from $440 \mu \mathrm{gC} \mathrm{g}{ }^{-1} \mathrm{DM}$ to $131 \mu \mathrm{gC} \mathrm{g}{ }^{-1} \mathrm{DM}$ in warmed conditions over two years (Table $\mathrm{S} 1$ ). Although the decrease of the biomass of testate amoebae with high trophic level was not significant at the litter layers $(F=3.9, P=0.063)$, the trend of their response followed that of testate amoebae in surface layers with a decrease of $28 \%$ and $41 \%$ of their biomass after one 
and two warming years respectively (Table S1). Moreover, we recorded that the warming effect on the abundance of main testate amoeba species was positively correlated to the ratio shell aperture size over body size at the surface layers $(\mathrm{r}=0.68, F=4.25, P<0.04$; Fig.1c). Here again, such trend was non-significant in the litter $(\mathrm{r}=0.36, F=2.3, P=0.17)$. We further observed that the microbial network from surface and litter became increasingly enriched in bacteria and depleted in top-predators with warming. The relative biomass of bacteria in the surface layers significantly increased from $31 \%$ in ambient plots to $45 \%$ in warmed plots, and from $29 \%$ to $36 \%$ in the litter layers (Fig. 2, Table S1). In parallel, the relative biomass of testate amoebae with high trophic level decreased from $31 \%$ in ambient plots to $12 \%$ in warmed plots in the surface layers and from $21 \%$ to $11 \%$ in the litter layers respectively. Consequently, the decrease in testate amoebae with high trophic level explained $10 \%(F=4.86, P=0.03)$ and $16 \%(F=7.91, P<0.01)$ of the rise of the relative bacterial biomass in warmed plots from surface and litter, respectively.

\section{Water chemistry composition}

PRC analysis showed that water chemistry composition was not affected by warming $(F=$ $2.1, P=0.11$ ). Time mainly explained the variance in water chemistry composition with $17 \%$ of the total variation. However, variance partitioning revealed a significant interaction between time and temperature increase on water chemistry composition with $21.9 \%$ of the variance (Table 1). Warming slightly affected water chemistry composition over the course of the two years. Elevated temperatures modified the annual dynamic of some chemical components such as $\mathrm{PO}_{4}{ }^{3-}, \mathrm{DOC}$, and $\mathrm{NO}_{3}{ }^{-}$(Table 2), even if these variations remained very low. Most importantly, we found in warmed plots that nitrates $(\mathrm{r}=-0.64, F=8.4, P<0.01)$ and DOC $(\mathrm{r}=-0.66, F=3.8, P=0.05)$ were negatively correlated to the decrease of the biomass of the testate amoebae with high trophic levels, whereas no such relationships were 
found in ambient plots (Fig. 3a, b, c). In the same way, no such relationships were found with the biomass of the testate amoebae with low trophic levels, both in ambient and warmed plots.

Aboveground subsystem

\section{Mosses and vascular plants abundances}

Plant community structure was stable across years and did not respond to warming over the course of the two years, as showed by the PRC $(F=0.61, P=0.96)$. Our results revealed that microtopography highly affected the composition of vegetation communities across the vegetation patterns $(F=12.8, P=0.001$; Table 1$)$. The detailed examination of the warming effect on vegetation in lawns and hummocks showed that the total abundance of vascular plants significantly increased with warming in both microtypes $(F=5.1, P=0.032$, ANOVA) and that of mosses decreased in lawns $(F=7.15, P=0.019$, ANOVA). Total vascular plant abundance increased from $29 \%$ of mean number of hits to $31 \%$ in lawns and from $37 \%$ of mean number of hits to $41 \%$ in patterns of hummocks and hollows (Fig. 4a). Such increase was due to a rise in the abundance of the evergreen low shrub Andromeda polifolia $(F=8.37$, $P<0.01$; Fig. 4c). The abundance of other evergreen vascular plants (Eriophorum vaginatum, Vaccinium oxycoccus), graminoids (Carex limosa, C. rostrata, C. pauciflora) and forbs (Drosera rotundifolia) did not respond to climate warming. Total moss abundance decreased in lawns from $55 \%$ to $45 \%$ after two warming years (Fig. 4b), especially Sphagnum fallax which significantly decreased from $49.0 \%$ to $42.9 \%(F=4.1, P=0.03$; Fig. 4 d). Other moss species such as $S$. magellanicum and $S$. palustris did not respond to warming.

Sphagnum-polyphenols. Total water-soluble polyphenol content was comprised between 0.5 mg. $\mathrm{g}^{-1}$ DM and $2.5 \mathrm{mg} \cdot \mathrm{g}^{-1}$ DM (Table 2). Phenolic content was not affected by warming over the course of the two warming years, but a significant negative link between phenolics and air 
temperatures was found. Furthermore, we found a negative relationship between watersoluble polyphenol and the biomass of testate amoebae with high trophic levels in warmed plots $(\mathrm{r}=-0.6, F=9.9, P<0.01)$ whereas the same relationship in ambient plots was not significant ( $\mathrm{r}=-0.2, F=1.7, P=0.21$ ) (Fig. 5). Moreover, variance partitioning revealed that water-soluble polyphenols and temperature increase explained $13 \%(F=6.2, P=0.018)$ and $19 \%(F=8.9, P=0.005)$ of the decrease of the biomass of testate amoebae with high trophic levels at the surface layers, respectively. Here again, such relationship was not found with testate amoebae with low trophic levels, as well as in the litter layers.

\section{Effect of warming on above- and belowground linkages}

The use of a path-relation network showed that warming affected above- and belowground interactions (Fig. 6). The final models adequately fitted the data under ambient $\left(\chi^{2}{ }_{7}=6.51, P\right.$ $=0.51 ; \mathrm{AIC}=34.19 ; \mathrm{GFI}=0.88 ; \mathrm{RMSEA}<0.001 ; \mathrm{RMR}=0.14)$ and warmed conditions $\left(\chi^{2} 7\right.$ $=1.00, P=0.99 ; \mathrm{AIC}=29.03 ; \mathrm{GFI}=0.98 ; \mathrm{RMSEA}<0.001 ; \mathrm{RMR}=0.034)$. Under ambient conditions, the model showed that microbial community structure in surface layers had significant links to microbial community structure in litter $(P<0.01)$, and that Sphagnumpolyphenols were negatively linked to microbial community structure in surface and litter $(P$ $=0.09$ ) (Fig. 6a). Significant associations were further found between microbial communities living in litter and water chemistry composition $(P<0.01$; Fig. 6a). The model also showed a strong negative association between moss community and vascular plant community $(P<$ 0.01). The ambient model explained a low proportion of the variance in mosses (8\%) and microbial community structure at the surface (2\%), whereas it explained $17.5 \%, 25.5 \%$ and $46.4 \%$ of microbial community structure in litter, water chemistry, and vascular plant community, respectively (Fig. 6a). 
In warmed plots, treatment effect on testate amoebae with high trophic level significantly increased the link of microbial communities living in surface with moss community structure $(P<0.01$; Fig. 6b). The link between Sphagnum-polyphenols and microbial communities also increased and shifted from a negative association in ambient plots to a positive association in warmed plots, especially on microorganisms living in surface layers. This analysis also revealed a decrease of the negative association between mosses on vascular plants community structure in warmed conditions. Moreover, the model showed that the relationships between water chemistry and microbial communities increased with warming, especially in litter layers $(P<0.01)$. The SEM model on warmed plots explained a larger proportion of the variance in moss community structure (19.4\%), water chemistry (49.7\%), microorganisms in surface (13\%) and litter (27.3\%) layers, whereas that of vascular plants diminished (19.5\%) (Fig. 6b). 


\section{Discussion}

Our results from a field manipulation experiment in a Sphagnum peatland show that warming affects total vascular plant and moss abundances as well as the structure and functioning of soil microbial communities so resulting in a modification of linkages between above- and belowground subsystems.

Warming effect on microbial communities resulted to rapid trophic alteration in the microbial food web. The impact of warming on microbial structure decreased with depth; the response of microbial communities was highly significant in the surface layers, similar but weaker in the litter layers. Such result is in line with previous observations of a weak warming effect on Sphagnum-polyphenol, enzymatic activities and water-extractable organic matter at this depth (Delarue et al., 2011; Jassey et al., 2011a; Jassey et al., 2012b). Warmed communities disproportionately lost top-predators and omnivores, and became increasingly dominated by decomposers and autotrophs (Fig. 2), showing that the stability of the microbial food web was affected by warming (Petchey et al., 1999; Dossena et al., 2012; Heckmann et al., 2012). More specifically, warming impacted testate amoebae with a large body size and shell aperture size, key organisms of the structure and functioning of microbial network due to their position at the top of the food web (Mitchell et al., 2003; Wilkinson \& Mitchell, 2010; Jassey et al., 2012a). This decrease was linked and coincided with an increase in the relative biomass of bacteria, both in the surface and litter layers. Such changes in the relative distribution of microbial group among trophically defined levels potentially lead to differences in ecosystem functioning beyond those expected from ambient conditions (Petchey et al., 1999, 2008; Dossena et al., 2012). Although it was not explore here, warming has been recognized to alter the structure of bacterial communities by favouring bacterial communities over methanogens, which may result changes in balance between $\mathrm{CO}_{2}$ and $\mathrm{CH}_{4}$ fluxes from peatlands (Kim et al., 2012). Furthermore, the strong impact of climate warming 
on testate amoebae is of particular interest because they link mosses and microbial heterotrophic producers (i.e. fungi and bacteria) via the microbial loop. This loop describes a trophic pathway in microbial food web where dead organic matter is returned to higher trophic levels via its incorporation into bacterial biomass coupled with the microbial food chains (e.g. bacteria $\rightarrow$ ciliate $\rightarrow$ testate amoebae; Gilbert et al., 1998). This recycles C and nutrients from dead organic matter to plant communities (Ledeganck et al., 2003; Mitchell et al., 2003). The decline of testate amoebae with high trophic levels probably caused a shortening of microbial food chains that sould greatly affect the microbial food web stability and structure, which further could destabilize ecosystem processes they control (Petchey et al., 1999; Mitchell et al., 2003; Wilkinson \& Mitchell, 2010; Heckmann et al., 2012). Indeed, testate amoebae with large shell aperture consume a wide range of prey such as small testate amoebae, ciliates, rotifers and small nematodes, typically bacterivores and algivores species (Wilkinson \& Mitchell, 2010; Jassey et al., 2012a). Such decrease could accelerate the turnover of microbial biomass due to the diminution of their top-down control (predation), speeding up decomposition and nutrient recycling via the microbial loop in long-term (Petchey et al., 1999; Mitchell et al., 2003; Dossena et al., 2012). Thus these changes in microbial community structure and stability suggest that climate warming will impact belowground subsystem functioning (Allison \& Martiny, 2008).

Interestingly, in other Sphagnum-dominated peatlands, summer warming accelerates nitrogen cycling due to changes in belowground subsystem (Weddon et al., 2012). In our study, the largest differences in water chemistry composition were found amongst sampling years. Annual variations in evapotranspiration and oxido-reduction processes associated with the water table position probably explained these variations (Proctor, 1994; Andersen et al., 2010). However, our results highlighted that water chemistry composition responded to warming in interaction with annual variations by slightly increasing nutrient (as $\mathrm{NO}_{3}{ }^{-}$) and $\mathrm{C}$ - 
exports (as DOC) levels in the soil solution after two years. Reasons of such slight effect may be explained by the fact that microorganisms living in surface layers are exposed to the chemistry of capillary water rather than water deeper in the peat (i.e. water table) (Lamentowicz et al., 2010). As a consequence of this vertical gradient, the relationships between bryophyte and water deeper in the peat are not optimal (Mitchell et al., 2000b; Hajkova et al., 2004). Warming effects on water chemistry would have been probably higher on water extracted from mosses themselves but this was not analysed here. Nevertheless, increasing amount of $\mathrm{DOC}$ and $\mathrm{NO}_{3}{ }^{-}$in warmed plots, even varying annually, may be interpreted as an indication of a slight destabilization of the belowground functioning of peatland (Evans et al., 2005; Carrera et al., 2009; Weddon et al., 2012). Moreover, the actual amount of $\mathrm{C}$ and nutrient fluxes from the microbial loop is dependent of the length of food chains in microbial food webs (Pomeroy, 2006). Thus, the negative correlations between $\mathrm{NO}_{3}{ }^{-}$ /DOC and the biomass of testate amoebae with high trophic levels suggest that the trophic alteration of the microbial structure due to potential shortening of food chains affected these biogeochemical fluxes.

We clearly showed that warming affected belowground subsystem, however, these phenomena are often indirectly linked to changes in aboveground communities (Wardle et al., 2004). A growing number of studies have showed how changes in plant communities affect soil communities (Wardle et al., 1999; Kardol \& Wardle, 2010) and how the soil biota in turn affects the plant community, leading to feedbacks between the plant and soil subsystems (De Dyn et al., 2003; Kardol et al., 2006; Wardle et al., 2012). The increase of vascular plants and the decrease of Sphagnum in response to warming probably modified the quantity and/or quality of plant-derived organic matter, which in turn affected microbial communities (Delarue et al., 2011). Although it was not explored here, we cannot exclude an increase of root exudates from vascular plants associated to their increase in response to warming, which 
could stimulate decomposers such as bacteria (Delarue et al., 2011). In addition, we revealed significant relationships between Sphagnum-polyphenols and microbial communities in warmed plots, suggesting these aboveground factors interact in driving belowground subsystem. Sphagnum-polyphenols play a fundamental ecological role in the regulation of soil microbiota and hence of microbial processes by way of chemical interactions (Hättenschwiler \& Vitousek, 2000; Inderjit et al., 2011; Jassey et al., 2011a). For the first time, we found that warming greatly impacted polyphenol-microbial community interactions by a shift from a negative to a positive effect in warmed conditions (Fig. 6), and that the amount of Sphagnumpolyphenols have a similar influence than warming on key microorganisms such as testate amoebae. The strong negative correlation between polyphenols and testate amoebae with high trophic levels in warmed conditions revealed a potential inhibitory effect of phenols on this category of microorganisms in context of warming (Jassey et al., 2011b). Even if warming did not directly impact the total amount of Sphagnum-polyphenols, qualitative changes induced by climate change are quite possible, as previously showed in dwarf shrubs ecosystems (Hansen et al., 2006). Such findings strongly suggest that polyphenols produced by Sphagnum play a key role in the regulation of testate amoebae community structure, as well as in the microbial network stability in ways that can positively affect decomposition (Jassey et al., 2011b; Inderjit et al., 2011). Indeed, by their inhibitory effect on top-predators, polyphenols may indirectly enhance $\mathrm{C}$ and nutrient mineralization. Bacterial growth and microbial OM breakdown could be stimulated by such inhibition of top-predators, leading to an increase of nutrient levels and $\mathrm{C}$ release in peatlands, which further would destabilize the productivity of plant communities and peatland carbon stock (Wardle et al., 2004; Fenner \& Freeman, 2011; Jassey et al., 2011a).

Reciprocally, we also assume that direct effects of climate warming on the microbial food web modify the linkages between above- and belowground communities. Warming 
effect on microbial food webs could greatly influence aboveground productivity and plant community structure through the stimulation of nutrient dynamics, which indirectly influence nutrient uptake of aboveground consumers such as vascular plants (Mitchell et al., 2003; Carlson et al., 2010; Kardol \& Wardle, 2010). The rise of temperature involved a decrease of the negative link between mosses and vascular plants, highlighting a reduction of Sphagnum mosses repression on vascular plant life (Fig. 6), as shown in response to other perturbations such as fertilization and drainage (Berendse et al., 2001; Lang et al., 2009). Even if vegetation composition did not change overall with warming, we recorded significant changes in total vegetation cover in course of two years of warming with a decrease of Sphagnum in lawns and an increase of vascular plants in lawns and hummocks. The observed slight increases of nutrient and $\mathrm{C}$ levels in soil solution are likely to alter the competition between mosses and vascular plants (Berendse et al., 2001; Keuper et al., 2011). Sphagnum mosses are known to be efficient at absorbing nitrogen, preventing deep-rooted vascular plants growing in a dense Sphagnum carpet (van Breemen, 1995; Turetsky, 2003; Gunnarsson, 2005), but excessive tissue nitrogen accumulation due to warming effect on the microbial food web should exacerbate the decline of Sphagnum and the increase of vascular plants (Breeuwer et al., 2008, 2009; Limpens \& Berendse, 2003). Such a warming-induced increase of vascular plant cover would further contribute to diminishing carbon sequestration in Sphagnum-peatlands due to a plant litter more easily degradable (Verhoeven \& Toth, 1995).

We conclude that climate warming greatly destabilises peatland functioning by changing the interactions between plant and microbial communities. These results imply that warming changes peatlands directly by modifying the structure of microbial communities with the loss of top-predators and the increase of bacteria and indirectly by changing ecosystem functions via modifications of plant-soil-microbial interactions through the increase of nutrients cycling and the positive and/or negative effect of Sphagnum-polyphenol 
on the microbial food web. Our observations support the hypothesis that microbial food web associated to mosses positively contribute to global warming by controlling ecosystem feedbacks (Lindo \& Gonzalez, 2010; Singh et al., 2010; Jassey et al., 2011b). Consequently the moss-microbiota system exerts a strong control over the structure and dynamics of peatland ecosystems. Furthermore, these key findings add another crucial new contributor to the list of mechanisms by which mosses, as ecosystem engineers, tightly regulate biogeochemical cycling and climate feedback in peatlands (van Breemen, 1995; Cornelissen et al., 2007; Gornall et al., 2007). 


\section{Acknowledgements}

This research is a contribution of the ANR PEATWARM project (Effect of moderate warming on the functioning of Sphagnum peatlands and their function as carbon sink). PEATWARM is supported by the French National Agency for Research under the “Vulnerability: Environment_Climate” Program (ANR-07-VUL-010). Further funding was provided to VEJ.J by the Franche-Comté Region, to A.B by EPFL and WSL, and to EAD.M by WSL, EPFL and University of Neuchâtel. The authors would like to thank T. SimeNgando and J. Colombet (University of Clermont-Ferrand, FR) for their help with the flow cytometry, and G. Bernard for field assistance. R.D. Bardgett (University of Lancaster, UK) R. Payne (Manchester Metropolitan University, UK) and R.T.E. Mills (Swiss Federal Research Institute WSL, CH) are kindly acknowledged for their fruitful comments on the manuscript and English edits. 


\section{REFERENCES}

Andersen R, Rocherfort L, Poulin M (2010) Peat, water and plant tissue chemistry monitoring : a seven-year case-study in a restored peatland. Wetlands, 30, 159-170.

Bardgett RD \& Wardle DA (2010) Aboveground-Belowground Linkages, Biotic interactions, Ecosystem processes, and Global Change. Oxford Series In Ecology and Evolution, Oxford University Press, New York.

Bardgett RD, Freeman C, Ostle NJ (2008) Microbial contributions to climate change through carbon cycle feedbacks. ISME Journal, 2, 805-814.

Berendse F, Van Breemen N, Rydin H, Buttler A, Heijmans M, et al. (2001) Raised atmospheric $\mathrm{CO}_{2}$ levels and increased $\mathrm{N}$ deposition cause shifts in plant species composition and production in Sphagnum bogs. Global Change Biology 7: 591-598.

Breeuwer A, Heijmans M, Gleichman M, Robroek BJM, Berendse F (2009) Response of Sphagnum species mixtures to increased temperature and nitrogen availability. Plant Ecology, 204, 97-111.

Breeuwer A, Heijmans M, Robroek BJM, Berendse F (2008) The effect of temperature on growth and competition between Sphagnum species. Oecologia, 156, 155-167.

Buttler A (1992) Permanent plot research in wet meadows and cutting experiment. Vegetatio, 103, 113-124.

Carlson ML, Flagstad LA, Gillet F, Mitchell EAD (2010) Community development along a proglacial chronosequence: are above-ground and below-ground community structure controlled more by biotic than abiotic factor? Journal of Ecology 98: 1084-1095.

Carrera N, Barreal ME, Gallego PP, Briones MJI (2009) Soil invertebrates control peatland C fluxes in response to warming. Functional Ecology 23: 637-648.

Cornelissen JHC, Lang SI, Soudzilovskaia NA, During HJ (2007) Comparative cryptogam ecology: a review of bryophyte and lichen traits that drive biogeochemistry. Annals of Botany, 99, 987-1001.

Davidson EA \& Janssens IA (2006) Temperature sensitivity of soil carbon decomposition and feedbacks to climate change. Nature 440: 165-173.

De Deyn GB, Cornelissen JHC, Bardgett RD (2008) Plant functional traits and soil carbon sequestration in contrasting biomes. Ecology Letters, 11, 516-531.

De Deyn GB, Raaijmakers CE, Zoomer HR, Berg MP, de Ruiter PC, Verhoef et al. (2003) Soil invertebrate fauna enhances grassland succession and diversity. Nature, 422, 711713.

Delarue F, Laggoun-Défarge F, Buttler A, Gogo S, Jassey VEJ, Disnar JR (2011) Effects of short-term ecosystem experimental warming on water-extractable organic matter in an ombrotrophic Sphagnum peatland (Le Forbonnet, France). Organic Geochemistry 42: 1016-1024.

Dise NB (2009) Peatland response to global change. Science, 326, 810-811.

Dorrepaal E, Toet S, van Logtestijn RSP, Swart E, van de Weg MJ, Callaghan TV, Aerts R (2009) Carbon respiration from subsurface peat accelerated by climate warming in the subarctic. Nature, 460, 616-679. 
Dossena M, Yvon-Durocher G, Grey J, Montoya JM, Perkins DM, Trimmer M, Woodward G (2012) Warming alters community size structure and ecosystem functioning. Proceedings of the Royal Society B (in press) 10.1098/rspb.2012.0394

Eisenhauer N, Cesarz S, Koller R, Worm K, Reich PB (2012) Global change belowground: impacts of elevated $\mathrm{CO} 2$, nitrogen, and summer drought on soil food webs and biodiversity. Global Change Biology, 18, 435- 447.

Escofier B, Pages J (1994) Multiple factor-analysis (afmult package). Computational Statistics \& Data Analysis 18(1): 121-140.

Evans CD, Monteith DT, Cooper DM (2005) Long-term increases in surface water dissolved organic carbon: Observations, possible causes and environmental impacts. Environmental Pollution, 137, 55-71.

Fenner N \& Freeman C (2011) Drought-induced carbon loss in peatlands. Nature geoscience 4, 895-900.

Fenner N, Ostle NJ, McNamara N, Sparks T, Harmens H, Reynolds B, Freeman C (2007) Elevated $\mathrm{CO} 2$ effects on peatland plant community carbon dynamics and DOC production. Ecosystems 10(4): 635-647.

Gilbert D, Amblard C, Bourdier G Francez AJ (1998) The microbial loop at the surface of a peatland: Structure, function, and impact of nutrient input. Microbial Ecolology 35, 83-93.

Gilbert D, Mitchell EAD, Amblard C, Bourdier G Francez AJ (2003) Population dynamics and food preferences of the testate amoeba Nebela tincta major-bohemica-collaris complex (Protozoa) in a Sphagnum peatland. Acta Protozoologica, 42, 99-104.

Gillet F, Peter M, Ayer F, Butler R Egli S (2010) Long-term dynamics of aboveground fungal communities in a subalpine Norway spruce forest under elevated nitrogen input. Oecologia, 164, 499-510.

Gornall JL, Jonsdottir IS, Woodin SJ, Van der Wal R (2007) Artic mosses govern belowground environment and ecosystem processes. Oecologia, 153, 931-941.

Grace JB, Anderson TM, Olff H Scheiner SM (2010). On the specification of structural equation models for ecological systems. Ecological Monographs, 80, 67-87.

Grace JB, Anderson TM, Smith MD, Seabloom E, Andelman SJ, et al. (2007). Does species diversity limit productivity in natural grassland communities? Ecology Letters, 10, 680-689.

Grace JB \& Kelley JE (2006) A structural equation model analysis of postfire plant diversity in California shrublands. Ecological Applications, 16, 503-514.

Gunnarsson U (2005) Global patterns of Sphagnum productivity. Journal of Bryology, 27, 269-279.

Hájková P \& Hájek M (2004) Bryophyte and vascular plants responses to base-richness and water level gradients in western carpathian Sphagnum-rich mires. Folia Geobotanica 39, 335-351.

Hansen AH, Jonasson S, Michelsen A, Julkunen-Tiitto R (2006),Long-term experimental warming, shading and nutrient addition affect the concentration of phenolic compounds in artic-alpine deciduous and evergreen dwarf shrubs. Oecologia, 147, 111. 
Hattenschwiler S \& Vitousek PM (2000) The role of polyphenols in terrestrial ecosystem nutrient cycling. Trends in Ecology and Evolution, 15, 238-243.

Heckmann L, Drossel B, Brose U, Guill C (2012) Interactive effects of body-size structure and adaptive foraging on food-web stability. Ecology Letters, 15, 243-250.

Husson F, Josse J, Lê S \& Mazet J (2009) FactoMineR: Factor Analysis and Data Mining with R. In. R package, version 1.12 http://CRAN.R-project.org/package=FactoMineR.

Inderjit, Wardle DA, Karban R \& Callaway RM (2011) The ecosystem and evolutionary contexts of allelopathy. Trends in Ecology and Evolution, 26, 655-662.

IPCC (2007) Climate change 2007: the physical science basis summary for policymakers. In. Contribution of Working Group I to the Fourth Assement report of the IPCC.

Jassey VEJ, Chiapusio G, Gilbert D, Buttler A, Toussaint ML, Binet P (2011a) Experimental climate effect on seasonal variability of polyphenol/phenoloxidase interplay along a narrow fen-bog ecological gradient in Sphagnum fallax. Global Change Bioliogy, 17, 2945-2957.

Jassey VEJ, Gilbert D, Binet P, Toussaint ML, Chiapusio G (2011b) Effect of a temperature gradient on Sphagnum fallax and its associated living microbial communities: a study under controlled conditions. Canadian Journal of Microbiology, 57, 226-235.

Jassey VEJ, Shimano S, Dupuy C, Toussaint ML, Gilbert D (2012a) Characterizing the feeding habits of the testate amoebae Hyalosphenia papilio and Nebela tincta along a narrow "fen-bog" gradient using digestive vacuole content and ${ }^{13} \mathrm{C}$ and ${ }^{15} \mathrm{~N}$ isotopic analyses. Protist 163: 451- 464.

Jassey VEJ, Chiapusio G, Gilbert D, Toussaint M-L, Binet P (2012) Peroxidase and phenoloxidase activities in Sphagnum-dominated peatlands in a warming climate. Soil Biology and Biochemistry, 46, 49-52.

Jonsson M \& Wardle DA (2010) Structural equation modelling reveals plant-community drivers of carbon storage in boreal forest ecosystems. Biology Letters, 6, 116-119.

Josse J, Pages J, Husson F (2008) Testing the significance of the RV coefficient. Computational Statistics \& Data Analysis 53(1): 82-91.

Kardol P, Martijn Bezemer T \& van der Putten WH (2006) Temporal variation in plant-soil feedback controls succession. Ecology Letters, 9, 1080-1088.

Kardol P \& Wardle DA (2010) How understanding aboveground-belowground linkages can assist restoration ecology. Trends in Ecology and Evolution, 25, 670-679.

Keuper F, Dorrepaal E, Van Bodegom PM, Aerts R, Van Logtestijn RSP, Callaghan TV, Cornelissen JHC (2011) A Race for Space? How Sphagnum fuscum stabilizes vegetation composition during long-term climate manipulations. Global Change Biology, 17, 2162-2171.

Kim S-Y, Freeman C, Fenner N, Kang H (2012) Funtional and structural responses of bacterial and methanogen communities to 3-year warming incubation in different depths of peat mire. Applied Soil Ecology, 57, 23-30.

Lamentowicz M, Lamentowicz L, van der Knaap WO, Gabka M, Mitchell EAD (2010) Contrasting Species-Environment Relationships in Communities of Testate Amoebae, Bryophytes and Vascular Plants Along the Fen-Bog Gradient. Microbial Ecology, 59, 499-510 
Lang SI, Cornelissen JHC, Holzer A, ter Braak CJF, Ahrens M, Callaghan TV, Aerts R (2009) Determinants of cryptogam composition and diversity in Sphagnum-dominated peatlands: the importance of temporal, spatial and functional scales. Journal of Ecology, 97, 299-310.

Ledeganck P, Nijs ,I Beyens L (2003) Plant functional group diversity promotes soil protist diversity. Protist, 154, 239-249.

Legendre P \& Legendre L (1998) Numerical Ecology $2^{\text {nd }}$ Edition.

Limpens J \& Berendse F (2003) How litter quality affects mass loss and N loss from decomposing Sphagnum. Oikos, 103, 537-547.

Lindo Z \& Gonzalez A (2010) The Bryosphere: an integral and influential component of the earth's biosphere. Ecosystems, 13, 612-627.

Mitchell EAD, Borcard D, Buttler AJ, Grosvernier P, Gilbert D, Gobat JM (2000a) Horizontal distribution patterns of testate amoebae (Protozoa) in a Sphagnum magellanicum carpet. Microbial Ecology, 39, 290-300.

Mitchell EAD, Buttler A, Grosvernier P, Rydin H, Albinsson C, Greenup AL, Heijmans M, Hoosbeek MR, Saarinen T (2000b) Relationships among testate amoebae (Protozoa), vegetation and water chemistry in five Sphagnum-dominated peatlands in Europe. New Phytologist 145, 95-106.

Mitchell EAD, Gilbert D, Buttler A, Amblard C, Grosvernier P, Gobat JM (2003) Structure of microbial communities in Sphagnum peatlands and effect of atmospheric carbon dioxide enrichment. Microbial Ecology, 46, 187-199.

Oksanen J, Blanchet G, Kindt R, Legendre P, O'Hara RG, Simpson GL, Solymos P, Stevens MHH, Wagner H (2010) vegan: Community Ecology Package. R package version 1.17-1. http://CRAN.R-project.org/package=vegan.

Petchey OL, Beckerman AP, Riede JO, Warren PH (2008) Size, foraging, and food web structure. Proceedings of the National Academy of Sciences of the United States of America, 105, 4191- 4196.

Petchey OL, McPhearson PT, Casey TM, Morin PJ (1999) Environmental warming alters food-web structure and ecosystem function. Nature, 402, 69-72.

Pinheiro JC and Bates DM (2000) Mixed-Effects Models in S and S-PLUS. Springer.

Pomeroy L.R Food web connections: links and sinks. In Microbial systems: new frontiers. Proc. 8th Int. Symp. on Microbial Ecology Bell C.R, Brylinsky M, Johnson-Green P 2000pp. 81-87. Eds. Halifax, Canada:Atlantic Canada Society for Microbial Ecology.

Proctor MCF (1994) Seasonal and shorter-term changes in surface- water chemistry on four English ombrogenous bogs. Journal of Ecology, 82, 597-610

Robert P, Escoufier Y (1976) Unifying tool for linear multivariate statistical-methods - rvcoefficient. Journal of the Royal Statistical Society Series C-Applied Statistics 25(3): 257-265.

R Development Core Team (2010) R: A language and environment for statistical computing. R Foundation for Statistical Computing, Vienna, Austria.

Singh BK, Bardgett RD, Smith P, Reay DS (2010) Microorganisms and climate change: terrestrial feedbacks and mitigation options. Nature Review Microbiology, 8, 779-790. 
Tsyganov AN, Aerts R, Nijs I, Cornelissen JHC \& L B. (2012). Sphagnum-dwelling Testate Amoebae in Subarctic Bogs are More Sensitive to Soil Warming in the Growing Season than in Winter: the Results of Eight-year Field Climate Manipulations. Protist 163, 400-414.

Turetsky MR (2003) The role of bryophytes in carbon and nitrogen cycling. Bryologist, 106, 395-409.

van Breemen N (1995) How Sphagnum bogs down other plants. Tree, 10, 270-275.

van den Brink PJ and ter Braak CJF (1999) Principal response curves: analysis of timedependent multivariate responses of a biological community to stress. Environmental Toxicology and Chemistry, 18, 138-148.

Verhoeven JTA \& Toth E (1995) Decomposition of carex and sphagnum litter in fens - effect of litter quality and inhibition by living tissue-homogenates. Soil Biology and Biochemistry, 27, 271-275.

Veteli TO, Mattson WJ, Niemela P, Julkunen-Tiitto R, Kellomaki S, Kuokkanen K, Lavola A (2007) Do elevated temperature and $\mathrm{CO}_{2}$ generally have counteracting effects on phenolic phytochemistry of boreal trees? Journal of Chemical Ecology 33(2): 287296.

Ward SE, Bardgett RD, McNamara NP, Adamson JK \& Ostle NJ (2007) Long-term consequences of grazing and burning on northern peatland carbon dynamics. Ecosystems, 10, 1069-1083.

Wardle DA \& Bardgett RD (2002) Communities and Ecosystems: Linking the Aboveground and Belowground components. Princeton Univ. Press, Princeton NJ.

Wardle DA (2006) The influence of biotic interactions on soil biodiversity. Ecology Letters, 9, 870-886.

Wardle DA, Bonner KI, Barker GM, Yeates GW, Nicholson KS, Bardgett RD, Watson RN, Ghani A (1999). Plant removals in perennial grassland: Vegetation dynamics, decomposers, soil biodiversity, and ecosystem properties. Ecological Monograph, 69, 535-568.

Wardle DA, Jonsson M, Bansal S, Bardgett RD, Gundale M.J, Metcalfe DB (2012) Linking vegetation change, carbon sequestration and biodiversity: insights from island ecosystems in a long-term natural experiment. Journal of Ecology 100, 16-30.

Wardle DA, Bardgett RD, Van der Putten WH, Wall DH (2004) Linking between aboveground and belowground biota. Science, 304, 1629-1633.

Weddon JT, Kowalchuck GA, Aerts R, van Hal J, van Logtestijn R, Tas N, Röling WFM, van Bodegom PM (2012) Summer warming accelerates sub-artic peatland nitrogen cycling without changing enzyme pools or microbial community structure. Global Change Biology, 18, 138-150.

Wilkinson DM \& Mitchell EAD (2010) Testate Amoebae and Nutrient Cycling with Particular Reference to Soils. Geomicrobiology Journal, 27, 520-533.

Yeates GW \& Foissner W (1995) Testate amoebae as predators of nematodes. Biology and Fertility of Soils, 20, 1-7. 
Table

Table 1: Summary of RDA on microbial, plant and water chemistry data sets and environmental factors: fraction of variance explained and significance of individual variables taken alone or in interaction. ${ }^{a}$ Percentage of variance explained (adjusted R2).

\begin{tabular}{|c|c|c|c|c|c|c|c|c|}
\hline & \multicolumn{2}{|c|}{ Microbial communities (top) } & \multicolumn{2}{|c|}{ Microbial communities (inter) } & \multicolumn{2}{|c|}{ Plant communities } & \multicolumn{2}{|c|}{ Water chemistry composition } \\
\hline & $\%^{a}$ & F-value -value $^{P}$ & $\%^{a}$ & F-value $e^{P \text {-value }}$ & $\%^{a}$ & F-value ${ }^{P \text {-value }}$ & $\%^{a}$ & F-value ${ }^{P \text {-value }}$ \\
\hline Microtopography (Alt) & 13.7 & $8.6^{P=0.001}$ & 0.6 & $1.2^{P=0.35}$ & 26.0 & $12.8^{P=0.001}$ & 3.6 & $3.04^{P=0.036}$ \\
\hline Time & 6.6 & $3.7^{P=0.007}$ & 24.7 & $8.7^{P=0.001}$ & 0.6 & $1.2^{P=0.30}$ & 19.8 & $8.35^{P=0.001}$ \\
\hline delta $\mathrm{T}^{\circ} \mathrm{C}$ & 10.5 & $6.1^{P=0.001}$ & 14.3 & $7.9^{P=0.001}$ & 2.0 & $0.3^{P=0.89}$ & 1.7 & $2.3^{P=0.096}$ \\
\hline delta $\mathrm{T}^{\circ} \mathrm{C} *$ Year & 16.5 & $2.1^{P=0.06}$ & 33.8 & $4.1^{P=0.002}$ & 5.4 & $0.6^{P=0.63}$ & 21.9 & $2.95^{P=0.035}$ \\
\hline delta $\mathrm{T}^{\circ} \mathrm{C}$ * Alt & 22.5 & $0.44^{P=0.83}$ & 12.6 & $0.71^{P=0.63}$ & 24.5 & $1.1^{P=0.30}$ & 4.2 & $0.45^{P=0.82}$ \\
\hline
\end{tabular}


Table 2: Mean ( \pm SE) of water chemical variables measured in a Sphagnum-dominated peatland subjected to experimental warming (WAR) or ambient conditions (AMB) in 2008, 2009 and 2010. Significant warming effects are shown in bold (ANOVA tests). W = warming effect.

\begin{tabular}{|c|c|c|c|c|c|c|c|c|c|c|}
\hline & & \multicolumn{2}{|c|}{2008} & \multicolumn{2}{|c|}{2009} & \multicolumn{2}{|c|}{2010} & \multicolumn{3}{|c|}{ F-value $e^{P \text {-value }}$} \\
\hline \multirow{3}{*}{$\mathrm{pH}$} & & AMB & WAR & AMB & WAR & AMB & WAR & warming & time & microtopography \\
\hline & Mean & 3.88 & 3.41 & 4.54 & 4.23 & 3.96 & 3.91 & $1.97^{P=0.17}$ & $0.76^{P=0.39}$ & $4.2^{P=0.07}$ \\
\hline & SE & 0.03 & 0.17 & 0.30 & 0.26 & 0.05 & 0.07 & & & \\
\hline \multirow{2}{*}{$\mathrm{DOC}\left(\mathrm{mg} \mathrm{L}^{-1}\right)$} & Mean & 42.0 & 40.2 & 40.7 & 40.5 & 47.3 & 48.5 & $4.2^{P=0.001}$ & $87.2^{P=0.001}$ & $3.2^{P=0.11}$ \\
\hline & SE & 4.3 & 0.8 & 1.1 & 0.7 & 1.0 & 0.8 & & & \\
\hline \multirow{2}{*}{$\mathrm{DN}\left(\mathrm{mg} \mathrm{L}^{-1}\right)$} & Mean & 1.00 & 0.70 & 0.74 & 0.63 & 0.70 & 0.71 & $0.88^{P=0.35}$ & $1.8^{P=0.19}$ & $0.2^{P=0.90}$ \\
\hline & SE & 0.20 & 0.03 & 0.11 & 0.01 & 0.01 & 0.02 & & & \\
\hline \multirow{2}{*}{$\mathrm{PO}^{3-}\left(\mathrm{mg} \mathrm{L}^{-1}\right)$} & Mean & 1.9 & 2.3 & 11.5 & 10.5 & 10.1 & 9.7 & $8.93^{P=0.001}$ & $28.2^{P=0.001}$ & $0.17^{P=0.69}$ \\
\hline & SE & 0.2 & 0.7 & 2.3 & 0.2 & 0.3 & 0.3 & & & \\
\hline \multirow{2}{*}{ Ptot $\left(\mathrm{mg} \mathrm{L}^{-1}\right)$} & Mean & 12.4 & 13.4 & 20.3 & 19.6 & 11.7 & 13.5 & $0.24^{P=0.78}$ & $0.25^{P=0.61}$ & $0.55^{P=0.47}$ \\
\hline & SE & 0.4 & 0.8 & 2.2 & 2.2 & 0.5 & 2.0 & & & \\
\hline \multirow{2}{*}{$\mathrm{NH}^{+}\left(\mathrm{mg} \mathrm{L}^{-1}\right)$} & Mean & 55.0 & 50.2 & 43.4 & 51.5 & 43.2 & 40.2 & $1.1^{P=0.31}$ & $5.23^{P=0.03}$ & $4.32^{P=0.07}$ \\
\hline & SE & 6.2 & 1.7 & 2.6 & 2.8 & 2.2 & 9.3 & & & \\
\hline \multirow{2}{*}{$\mathrm{NO3}^{-}\left(\mathrm{mg} \mathrm{L}^{-1}\right)$} & Mean & 8.7 & 7.7 & 10.3 & 4.4 & 25.7 & 28.0 & $6.23^{P=0.02}$ & $21.2^{P=0.001}$ & $0.29^{P=0.59}$ \\
\hline & SE & 2.0 & 1.5 & 4.4 & 2.6 & 1.6 & 1.8 & & & \\
\hline \multirow{2}{*}{ Phenol (mg.g $\left.\mathrm{g}^{-1} \mathrm{DM}\right)$} & Mean & 1.20 & 1.11 & 1.00 & 0.95 & 1.49 & 2.31 & $0.03^{P=0.87}$ & $5.49^{P=0.03}$ & $10.4^{P=0.001}$ \\
\hline & SE & 0.06 & 0.07 & 0.09 & 0.13 & 0.20 & 0.22 & & & \\
\hline
\end{tabular}




\section{Figures}

Figure 1: Microbial community response to climate warming in a Sphagnum-dominated peatland. Principal response curve diagrams with scores for microbial functional groups living in the surface (a) $(P=0.02)$ and the litter $(\mathbf{b})(P=0.05)$ layers of the Sphagnum carpet. (c) Warming effect on testate amoeba species in relation to the size of their shell-aperture over their body size. The warming effect was determined using the $F$-value from ANOVA tests. Testate amoebae that contributed to less than $3 \%$ of maximum abundance in all samples were removed from the data set to reduce the influence of rare taxa in this analysis. Lines are regression line, asterisks indicate significant regression at $P<0.05$ level (ANOVA test).

Figure 2: Barplot of the relative contribution of microbial groups to the total microbial community (\% of total biomass) living at the surface (a) and litter (b) layers in ambient and warmed conditions. Asterisks indicate a warming effect (ANOVA tests). TAS $=$ testate amoebae with a low trophic level; TAB = testate amoebae with a high trophic level.

Figure 3: (a) Nitrates $\left(\mathrm{NO}_{3}{ }^{-}\right)$and (b) labile $\mathrm{C}$ (DOC) concentrations plotted against the biomass of testate amoebae with high trophic levels in ambient and warmed plots. Lines are regression line, asterisks indicate significant regression at $P<0.05$ level (ANOVA test).

Figure 4: Total abundance of (a) vascular plants and (b) mosses (expressed as \% of mean number of hits). Abundance of (c) Andromeda polifolia and (d) Sphagnum fallax (expressed as $\%$ of mean number of hits). Asterisks indicate significant differences between treatments $(P$ $<0.01$, ANOVA tests). 
Figure 5: Total water-soluble polyphenol content $\left(\mathrm{mg} \cdot \mathrm{g}^{-1} \mathrm{DM}\right)$ plotted against the biomass of testate amoebae with high size of shell aperture over body size ratio. Asterisks indicate significant differences between ambient and warmed plots (ANOVA tests).

Figure 6: Structural equation models of above- and belowground components in a Sphagnum-dominated peatland subjected to (a) ambient conditions or (b) experimental warming. Biomass of individual microbial groups living in surface and litter layers of Sphagnum carpet, percentage cover of moss and vascular plant species, polyphenols produced by Sphagnum, and water chemistry matrices were used to build the path-relation network. Dashed arrows indicate negative relationships. Numerals near each path indicate the weight of the path relationship; $* P<0.01$. 


\section{Supplementary information}

Table S1: Average biomass ( \pm SE) and average relative abundance $(\%)$ of microbial groups in a Sphagnum-dominated peatland subjected to experimental warming (WAR) or ambient conditions (AMB) in 2008, 2009 and 2010. Significant warming effect appeared in bold (ANOVA tests).

\begin{tabular}{|c|c|c|c|c|c|c|c|c|c|c|}
\hline \multirow[b]{2}{*}{ SURFACE } & & \multicolumn{2}{|c|}{2008} & \multicolumn{2}{|c|}{2009} & \multicolumn{2}{|c|}{2010} & \multicolumn{3}{|c|}{ F-values ${ }^{p \text {-values }}$} \\
\hline & & AMB & WAR & AMB & WAR & AMB & WAR & year & microtopography & warming \\
\hline \multirow{3}{*}{ Bacteria } & MEAN & 552 & 554 & 478 & 524 & 540 & 516 & $0.12^{P=0.71}$ & $0.12^{P=0.72}$ & $0.001^{P}=0.97$ \\
\hline & SE & 34 & 88 & 88 & 75 & 113 & 85 & & & \\
\hline & $\%$ & 28 & 26 & 25 & 31 & 31 & 45 & $0.49^{P=0.49}$ & $1.3^{P=0.28}$ & $14.8^{P=0.009}$ \\
\hline \multirow{3}{*}{ Fungi } & MEAN & 92 & 65 & 138 & 244 & 114 & 76 & $0.02^{P=0.91}$ & $26.1^{P=0.005}$ & $0.60^{P=0.45}$ \\
\hline & SE & 38 & 36 & 36 & 94 & 30 & 14 & & & \\
\hline & $\%$ & 5 & 3 & 14 & 7 & 7 & 7 & $0.78^{P=0.39}$ & $28.4^{P=0.003}$ & $4.3^{P=0.052}$ \\
\hline \multirow{3}{*}{ Microalgae } & MEAN & 325 & 476 & 515 & 371 & 264 & 226 & $0.49^{P=0.48}$ & $0.27^{P=0.61}$ & $1.5^{P=0.23}$ \\
\hline & SE & 78 & 250 & 250 & 104 & 68 & 45 & & & \\
\hline & $\%$ & 17 & 22 & 22 & 15 & 15 & 20 & $0.53^{P=0.47}$ & $1.3^{P=0.3}$ & $0.01^{P=0.92}$ \\
\hline \multirow{3}{*}{ Cyanobacteria } & MEAN & 28 & 50 & 36 & 16 & 14 & 7 & $1.57^{P=0.23}$ & $0.16^{P=0.69}$ & $2.9^{P=0.11}$ \\
\hline & SE & 15 & 20 & 20 & 6 & 6 & 2 & & & \\
\hline & $\%$ & 1 & 2 & 1 & 1 & 1 & 1 & $0.71^{P=0.41}$ & $0.19^{P=0.67}$ & $1.73^{P=0.21}$ \\
\hline \multirow{3}{*}{ Ciliate } & MEAN & 19 & 60 & 19 & 20 & 21 & 10 & $0.85^{P=0.36}$ & $0.05^{P=0.82}$ & $6.28^{P=0.02}$ \\
\hline & SE & 6 & 3 & 3 & 4 & 7 & 4 & & & \\
\hline & $\%$ & 1 & 3 & 1 & 1 & 1 & 1 & $0.8^{P=0.41}$ & $0.08^{P=0.78}$ & $2.2^{P=0.15}$ \\
\hline \multirow{3}{*}{ Rotifers } & MEAN & 342 & 386 & 140 & 135 & 112 & 87 & $28.8^{P=0.001}$ & $0.34^{P=0.58}$ & $31.5^{P=0.001}$ \\
\hline & SE & 78 & 28 & 28 & 32 & 28 & 29 & & & \\
\hline & $\%$ & 18 & 18 & 7 & 8 & 6 & 8 & $21.1^{P=0.002}$ & $0.23^{P}=0.24$ & $12.2^{P=0.002}$ \\
\hline \multirow{2}{*}{ Nematodes } & MEAN & 68 & 75 & 90 & 71 & 83 & 55 & $0.2^{P=0.68}$ & $3.6^{P=0.09}$ & $0.99^{P}=0.33$ \\
\hline & SE & 19 & 26 & 26 & 27 & 37 & 14 & & & \\
\hline
\end{tabular}




\begin{tabular}{|c|c|c|c|c|c|c|c|c|c|c|}
\hline & $\%$ & 4 & 3 & 5 & 4 & 5 & 5 & $0.36^{P=0.55}$ & $3.3^{P=0.09}$ & $0.36^{P=0.55}$ \\
\hline \multirow{3}{*}{$\begin{array}{c}\text { Testate amoebae } \\
\text { (small) }\end{array}$} & MEAN & 35 & 50 & 42 & 43 & 40 & 28 & $0.01^{P=0.91}$ & $0.001^{P=0.97}$ & $3.42^{P=0.08}$ \\
\hline & SE & 8 & 9 & 9 & 9 & 16 & 8 & & & \\
\hline & $\%$ & 2 & 2 & 2 & 2 & 2 & 2 & $0.09^{P=0.73}$ & $0.66^{P=0.44}$ & $0.09^{P}=0.73$ \\
\hline \multirow{3}{*}{$\begin{array}{c}\text { Testate amoebae } \\
\text { (large) }\end{array}$} & MEAN & 479 & 440 & 474 & 283 & 540 & 131 & $0.55^{P=0.47}$ & $5.95^{P=0.03}$ & $21.3^{P=0.001}$ \\
\hline & SE & 114 & 86 & 86 & 42 & 78 & 44 & & & \\
\hline & & 25 & 20 & 25 & 17 & 31 & 12 & $3.9^{P=0.061}$ & $4.36^{P=0.063}$ & $5.2^{P=0.03}$ \\
\hline \multicolumn{11}{|l|}{ LITTER } \\
\hline \multirow{3}{*}{ Bacteria } & MEAN & 778 & 847 & 840 & 857 & 718 & 962 & $0.15^{P=0.71}$ & $5.8^{P=0.04}$ & $1.1^{P=0.32}$ \\
\hline & SE & 183 & 133 & 133 & 43 & 156 & 159 & & & \\
\hline & $\%$ & 29 & 25 & 23 & 25 & 29 & 36 & $1.8^{P=0.19}$ & $0.26^{P=0.66}$ & $11.9^{P=0.002}$ \\
\hline \multirow{3}{*}{ Fungi } & MEAN & 283 & 436 & 974 & 1175 & 514 & 569 & $0.29^{P=0.59}$ & $2.72^{P=0.13}$ & $0.95^{P}=0.34$ \\
\hline & SE & 36 & 220 & 220 & 256 & 133 & 213 & & & \\
\hline & $\%$ & 11 & 13 & 27 & 34 & 21 & 21 & $3.8^{P=0.06}$ & $0.2^{P=0.66}$ & $5.1^{P=0.03}$ \\
\hline \multirow{3}{*}{ Microalgae } & MEAN & 178 & 207 & 266 & 281 & 241 & 361 & $0.93^{P=0.34}$ & $5.1^{P=0.05}$ & $2.24^{P=0.15}$ \\
\hline & SE & 51 & 70 & 70 & 82 & 66 & 95 & & & \\
\hline & $\%$ & 7 & 6 & 7 & 8 & 10 & 14 & $9.2^{P=0.002}$ & $0.2^{P=0.66}$ & $13.3^{P=0.015}$ \\
\hline \multirow{3}{*}{ Cyanobacteria } & MEAN & 35 & 27 & 37 & 154 & 41 & 30 & $0.05^{P=0.83}$ & $0.001^{P=0.97}$ & $0.32^{P=0.58}$ \\
\hline & SE & 27 & 10 & 10 & 71 & 26 & 18 & & & \\
\hline & $\%$ & 1 & 1 & 1 & 4 & 2 & 1 & $0.29^{P=0.59}$ & $0.86^{P=0.38}$ & $1.1^{P=0.30}$ \\
\hline \multirow{3}{*}{ Ciliate } & MEAN & 70 & 180 & 37 & 21 & 16 & 15 & $10.6^{P=0.023}$ & $4.5^{P=0.06}$ & $10.6^{P=0.004}$ \\
\hline & SE & 24 & 11 & 11 & 5 & 5 & 7 & & & \\
\hline & $\%$ & 3 & 5 & 1 & 1 & 1 & 1 & $12.4^{P=0.002}$ & $0.45^{P=0.64}$ & $7.5^{P=0.01}$ \\
\hline \multirow{3}{*}{ Rotifers } & MEAN & 436 & 637 & 222 & 225 & 118 & 83 & $32.6^{P=0.001}$ & $1.6^{P=0.24}$ & $31.9^{P=0.001}$ \\
\hline & SE & 53 & 39 & 39 & 60 & 39 & 36 & & & \\
\hline & $\%$ & 16 & 19 & 6 & 6 & 5 & 3 & $73.1^{P=0.001}$ & $0.65^{P=0.44}$ & $38.7^{P=0.001}$ \\
\hline \multirow{3}{*}{ Nematodes } & MEAN & 162 & 222 & 298 & 136 & 119 & 126 & $0.52^{P=0.47}$ & $0.02^{P=0.89}$ & $2.65^{P=0.12}$ \\
\hline & SE & 48 & 88 & 88 & 26 & 32 & 42 & & & \\
\hline & $\%$ & 6 & 6 & 8 & 4 & 5 & 5 & $0.29^{P=0.59}$ & $0.86^{P=0.38}$ & $1.1^{P=0.30}$ \\
\hline \multirow{2}{*}{$\begin{array}{c}\text { Testate amoebae } \\
\text { (small) }\end{array}$} & MEAN & 180 & 323 & 364 & 192 & 150 & 217 & $0.31^{P=0.58}$ & $0.03^{P=0.86}$ & $0.48^{P=0.49}$ \\
\hline & SE & 27 & 99 & 99 & 23 & 34 & 143 & & & \\
\hline
\end{tabular}




\begin{tabular}{clccccccccc} 
& $\%$ & 7 & 9 & 10 & 6 & 6 & 8 & $0.12^{P=0.74}$ & $2.24^{P=0.17}$ & $2.8^{P=0.11}$ \\
\hline \multirow{2}{*}{$\begin{array}{c}\text { Testate amoebae } \\
\text { (large) }\end{array}$} & MEAN & 543 & 561 & 604 & 438 & 521 & 307 & $0.06^{P=0.93}$ & $4.9^{P=0.051}$ & $3.85^{P=0.063}$ \\
& SE & 64 & 179 & 179 & 118 & 232 & 99 & & \\
& $\%$ & 20 & 16 & 17 & $\mathbf{1 3}$ & 21 & $\mathbf{1 1}$ & $0.22^{P=0.64}$ & $0.44^{P=0.45}$ & $10.7^{P=0.004}$ \\
\hline
\end{tabular}


(a)

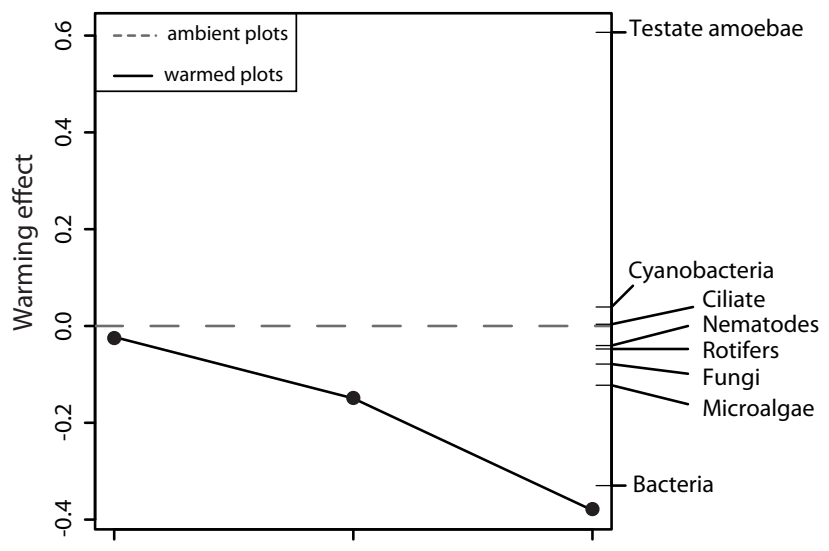

(b)
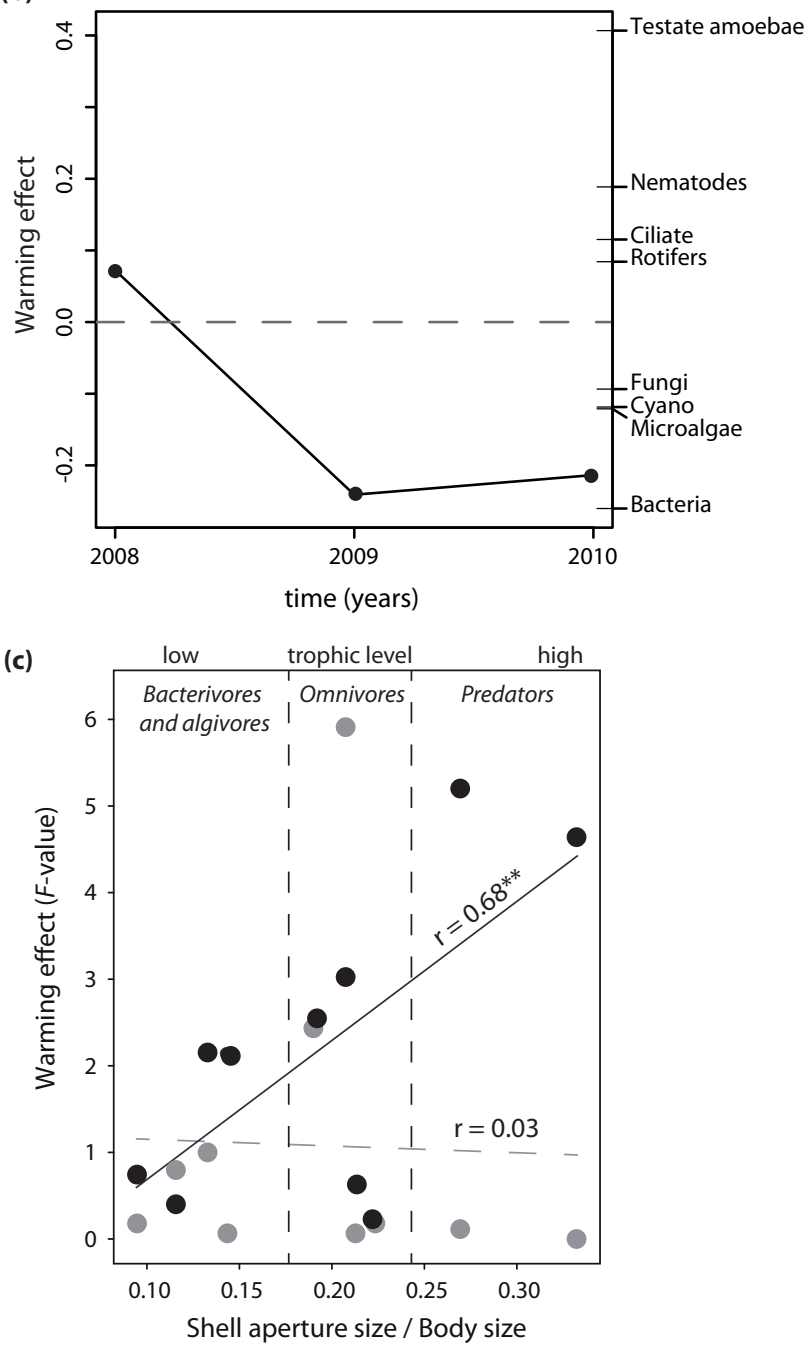

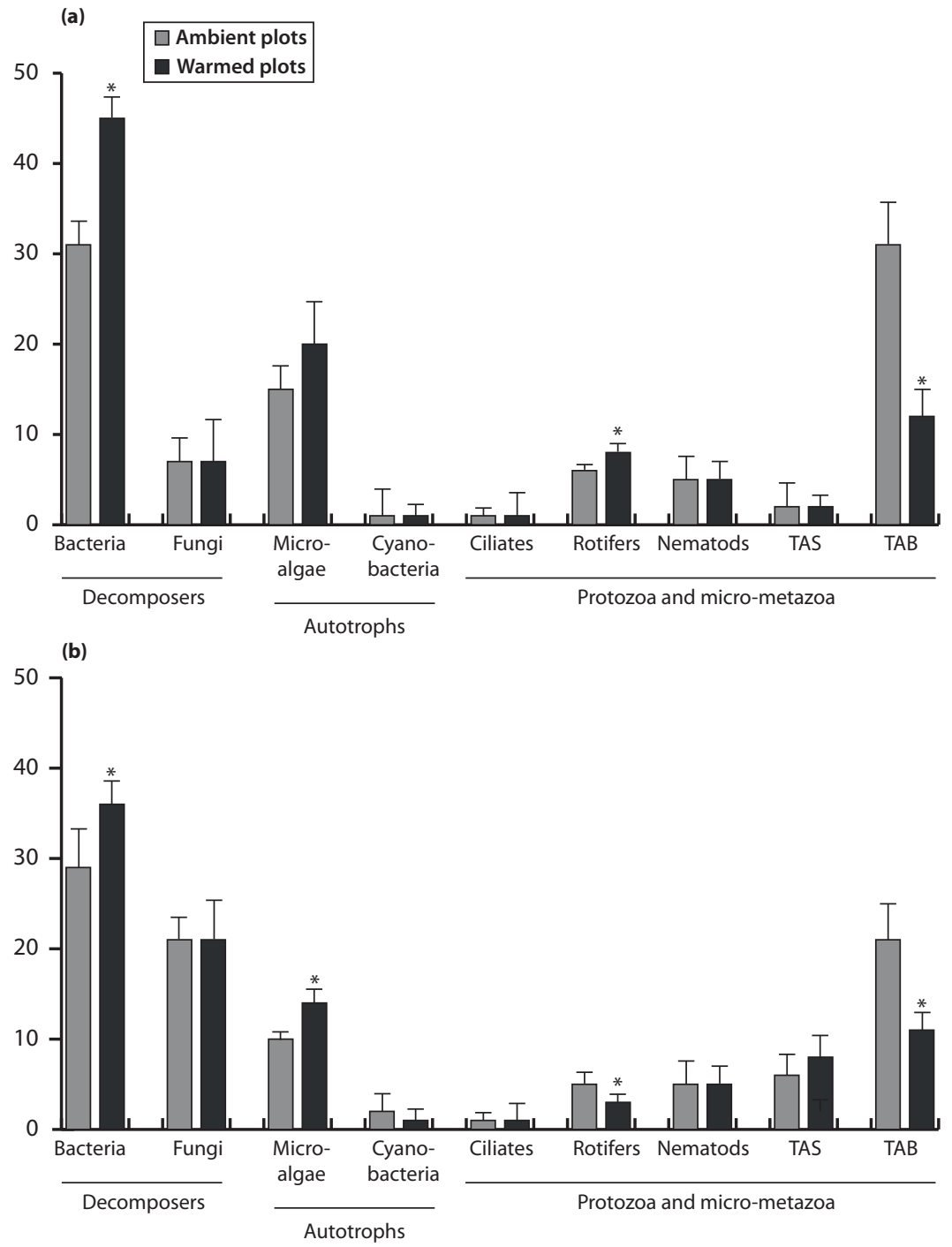
(a)

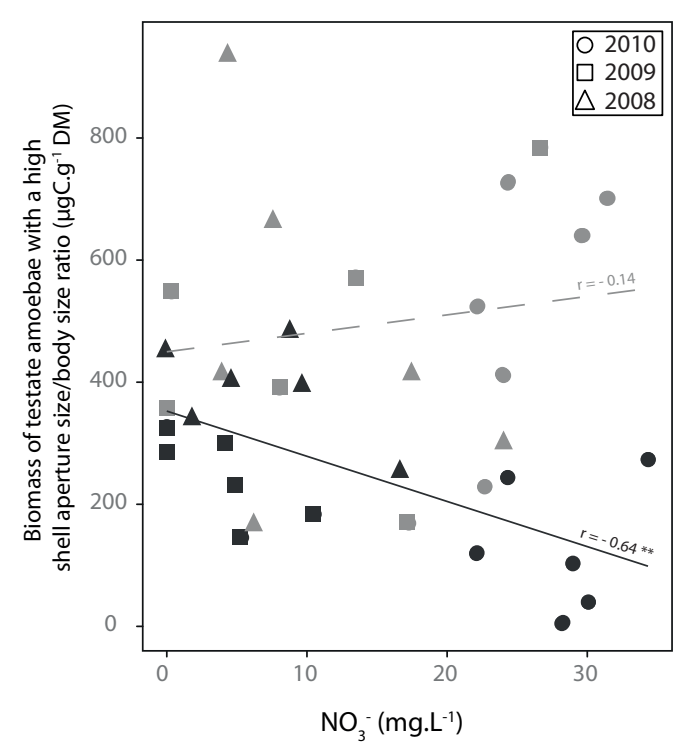

(b)

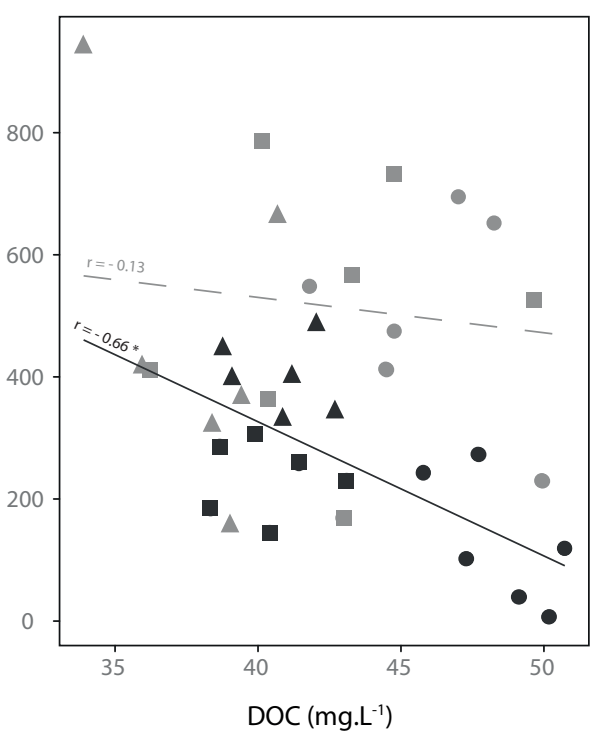


(a) Total abundance of vascular plants

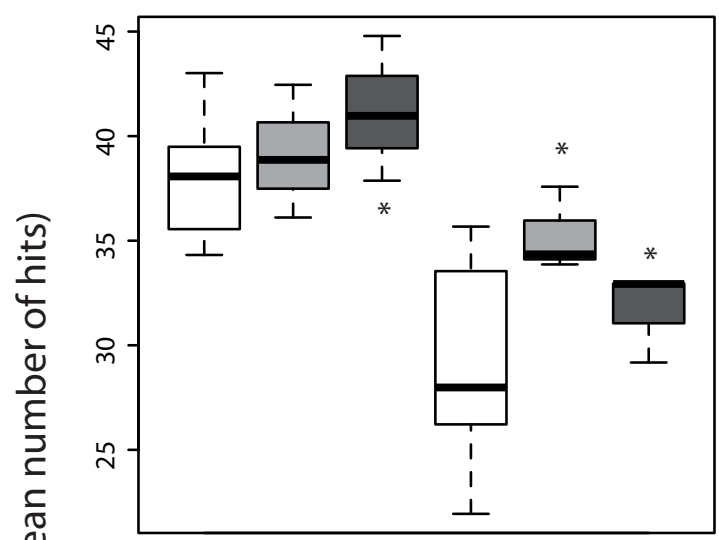

(c) Abundance of Andromeda polifolia

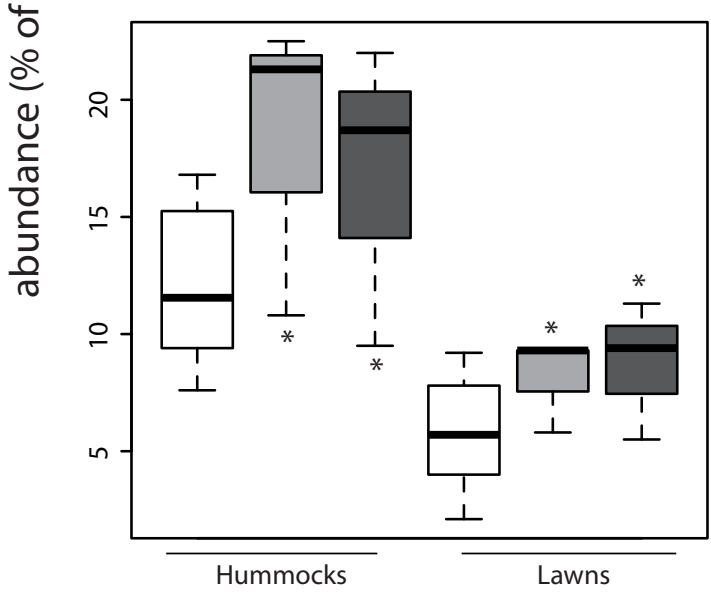

(b) Total abundance of mosses

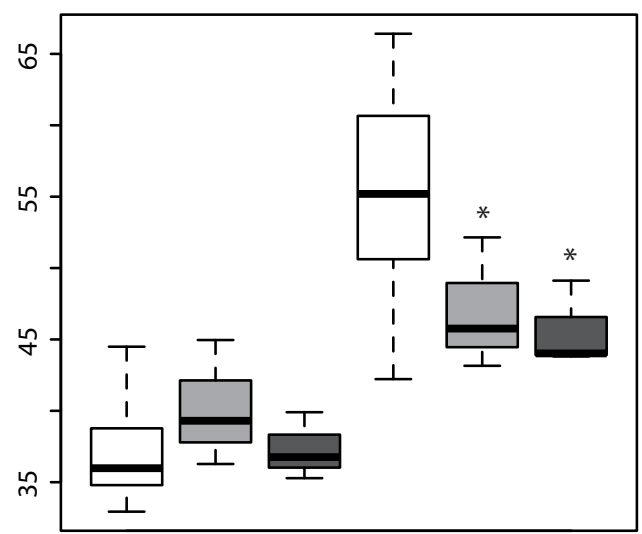

(d) Abundance of Sphagnum fallax

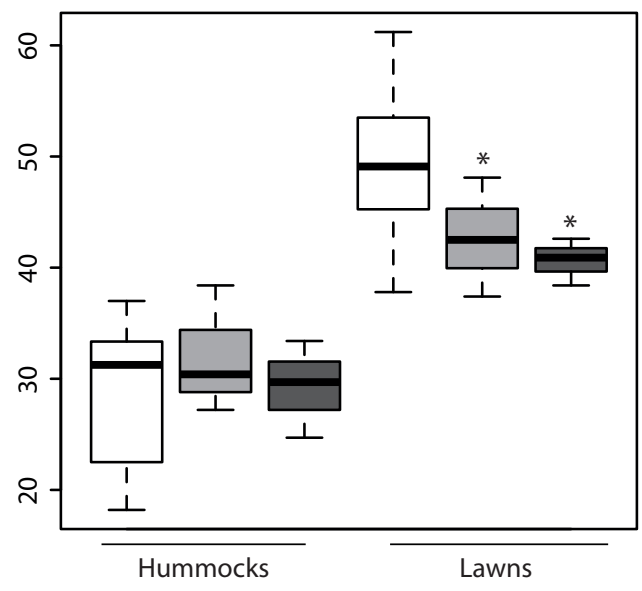

$\square$ 0year of warming $\square$ 1 year of warming $\square 2$ years of warming 


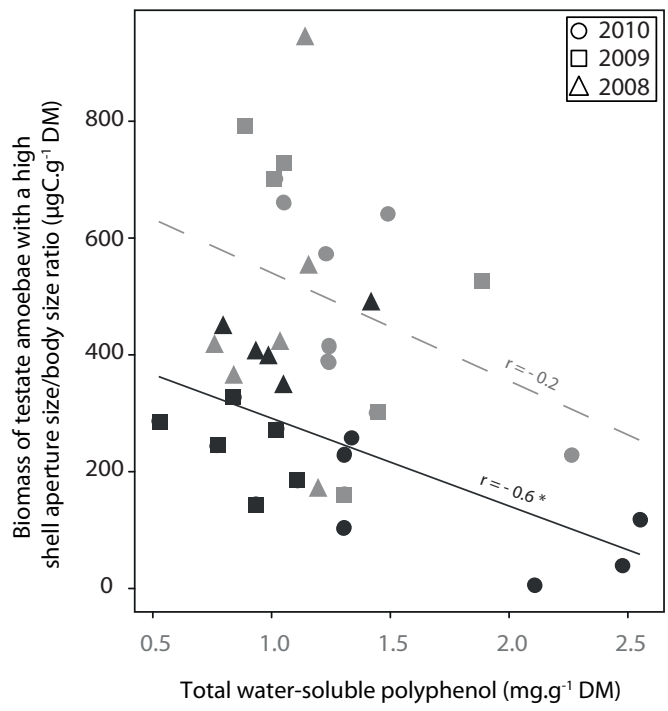



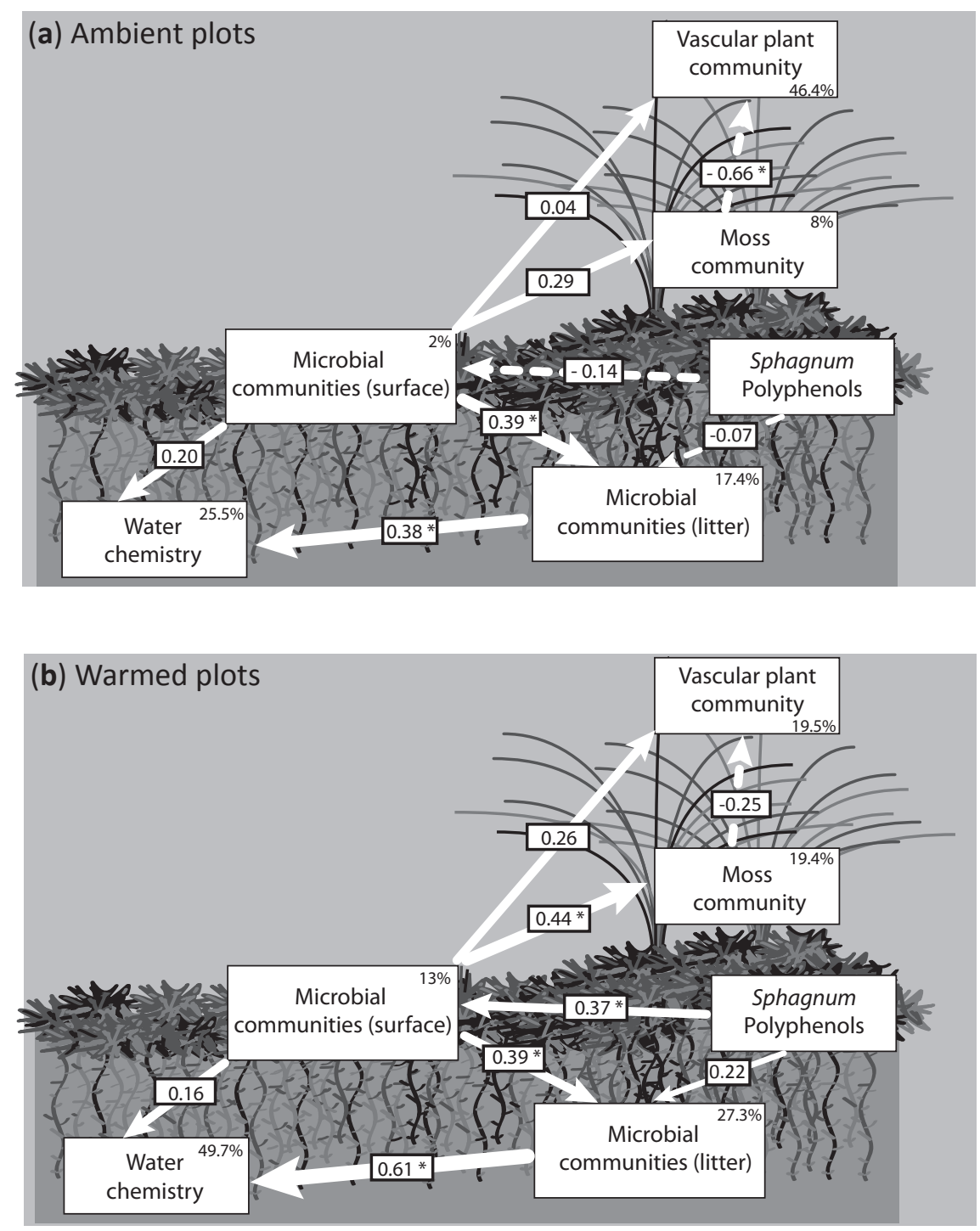